\title{
CAPSULE, LEAF AND CYATHIAL GLAND MORPHOLOGY OF TURKISH PERENNIAL TAXA OF Euphorbia L. SECTION Pithyusa (Raf.) Lázaro
}

\author{
İlker GENÇ*, Şükran KÜLTÜR, Gülay ECEVİT-GENÇ \\ İstanbul University, Faculty of Pharmacy, Department of Pharmaceutical Botany, İstanbul, TURKEY \\ *Corresponding author: e-mail: ilkgenc@istanbul.edu.tr
}

Cite this article as:

Genç İ., Kültür Ş., Ecevit-Genç G. 2018. Capsule, Leaf and Cyathial Gland Morphology of Turkish Perennial Taxa of Euphorbia L. Section Pithyusa (Raf.) Lázaro. Trakya Univ J Nat Sci, 19(1): 11-19, DOI: 10.23902/trkjnat.342096

Received: 06 October 2017, Accepted: 25 December 2017, Online First: 27 December 2017, Published: 15 April 2018

\begin{abstract}
Macro and micromorphology of cyathial glands, capsules and cauline leaf surfaces of 13 perennial species of Euphorbia L. subg. Esula Pers. sect. Pithyusa (Raf.) Lázaro in Turkey were studied. Cyathial gland structure, based on cyathial gland shapes, colour and appendages was examined from live material by direct field observations and investigations. Cauline leaves and capsule surface features were analysed with scanning electron microscopy (SEM). Capsule sizes, capsule shapes and capsule and cauline leaf surface ornamentations were also studied. The capsule shape was found to vary from subglobose to conical. In most species, cyathial gland colour ranged from greenish-yellow to yellowish-green but some species were distinguished by their reddish or purplish cyathial glands. Although the number of cyathial glands in all species was four, five cyathial glands were determined to exist in some specimens of E. pestalozzae Boiss. Three different cyathial gland shapes (elliptic, trapezoid-elliptic or elliptic-reniform) were observed. Capsule surface of more than half of the studied species (7 taxa) is covered with nipple-like projections (papillate-mammillate) and the rest are covered with tiny rounded or hillock-like ornamentation (colliculate). The cauline leaf surface is papillate-mammillate in the majority of the studied species, although, colliculate surface is also observed in two species (E. seguieriana Necker and E. thessala (Form.) Degen \& Dörf.). In conlusion, macro and micromorphological structures of cyathial gland and capsule of Euphorbia sect. Pithyusa taxa appeared to be useful diagnostic characters for species identifications.
\end{abstract}

Key words: Leafy spurge, micromorphology, leaf surface, subg. Esula, Euphorbiaceae.

Özet: Bu çalışma Euphorbia L. subg. Esula Pers. sect. Pithyusa (Raf.) Lázaro çok yıllık türlerinin siatyum gland şekilleri, kapsula ve gövde yaprak yüzey mikromorfolojilerine dayanmaktadır. Siatyum gland yapılarının incelenmesi doğrudan arazi çalışmaları sırasında canlı örnekler üzerinden yapılmıştır. Gövde yaprağı ve kapsulanın yüzey özellikleri taramalı elektron mikroskobu (SEM) ile incelenmiștir. Ayrıca kapsula boyutu, kapsula şekli, kapsula ve gövde yaprak yüzey özellikleri de incelenmiştir. Çalışılan türlerin kapsula şekilleri hemen hemen küresel'den koniğe değişir. Araştırılan türlerden çoğunun gland rengi parlak sarı-yeşil veya yeşilimsi sarıdır. Bazı türlerde ise glandlar kırmızı veya mor renkli olabilir. Tüm türlerde gland sayıları E. pestalozzae Boiss. haricinde dörttür. Bu türün bazı bireylerinin 5 glandlı olduğu saptanmıştır. Üç farklı gland şekli (eliptik, trapezoid-eliptik veya böbreksi) gözlenmiştir. kapsula yüzeyleri, incelenen türlerin yarısından fazlasında (7 takson) meme başı benzeri çıkıntılarla (papillat-mammillat) kaplı iken, diğer türlerde küçük yuvarlak veya tepecik benzeri yükseltilerle (kollikulat) kaplıdır. İncelenen türlerin çoğunluğunda gövde yaprak yüzeyleri papillat-mammillattır. Kollikulat yüzeyler de iki türde görülmüștür (E. seguieriana Necker ve E. thessala (Form.) Degen \& Dörf.) Sonuç olarak, Euphorbia sect. Pithyusa türlerine ait gland ve kapsula morfolojik özelliklerinin türlerin ayrımında ayırt edici karakterler olarak kullanılabileceği gösterilmiştir.

\section{Introduction}

Euphorbia L. is one of the largest genera of flowering plants with more than 2000 species distributed throughout the world. Life forms within the genus vary from tiny annuals to perennial herbs and trees (Bruyns et al. 2006, Horn et al. 012). Previous phylogenetic studies on Euphorbia yielded results used for separation of the genus into four main clades corresponding four subgenera as Athymalus Neck. ex. Rchb., Chamaesyce Raf., Esula Pers. and Euphorbia (Steinmann \& Porter 2002, Bruyns et al. 2006, Zimmerman et al. 2010, Horn et al. 2012, Yang et al. 2012, Dorsey et al. 2013, Peirson et al. 2013, Riina et al. 2013). Genus Euphorbia is represented in Turkey by two subgenera Chamaesyce and Esula with a total of 120 taxa (Öztekin 2012, Genç \& Kültür 2016).

Subgenus Esula comprises about 490 species most of which are annual or perennial herbs mostly distributed in the temperate regions of the northern hemisphere in the Old World (Geltman 2015, Pahlevani et al. 2017). Temperate Eurasia, particularly the Mediterranean and the IranoTuranian regions are two most important diversity centres of Euphorbia subgenus Esula (Riina et al. 2013). 
Turkish subgenus Esula has recently been embedded and classified, based on recent molecular studies, into 14 sections [Arvales (Geltman) Geltman, Chylogala (Fourr.) Prokh., Esula (Pers.) Dumort., Exiguae (Geltman) Riina \& Molero, Helioscopia Dumort., Lagascae Lázaro, Lathyris Dumort., Myrsiniteae (Boiss.) Lojac., Pachycladae (Boiss.) Tutin, Paralias Dumort., Patellares (Prokh.) Frajman, Pithyusa (Raf.) Lázaro, Szovitsiae Geltman and Tithymalus (Gaertn.) Roep.] (Riina et al. 2013).

17 species of the 60 reported species of Euphorbia sect. Pithyusa occur in Turkey. Turkey is the second most species-rich country after Iran both in the number of species and endemics in sect. Pithyusa (Pahlevani 2017). The members of the section are mostly characterized by semisucculent and glaucous leaves, palmate leaf venation, papillose indumentum, usually entire leaf margin, conical or nearly so rounded capsules and elliptic or trapezoidal cyathial glands (Riina et al. 2013).

The only comprehensive study on the genus Euphorbia in Turkey was performed by Radcliffe-Smith (1982) and the last morphological study concerning the genus was made by Can \& Küçüker (2015).
Seed, capsule and cyathial gland morphologies are useful parameters used in distinguishing taxa in Euphorbia (Pahlevani \& Akhani 2011, Salmaki et al. 2011, Riina et al. 2013, Pahlevani et al. 2015). However, detailed studies are missing especially for most species distributed in Turkey, raising the need of comprehensive studies on seed, capsule and cyathial gland morphologies of Turkish Euphorbia. We, therefore, aimed in the present study to provide a detailed description and importance of capsula and cyathial gland morphology of perennial Turkish Euphorbia sect. Pithyusa. We also investigated the micromorphology of the cauline leaf surfaces after determining some variations on leaf surfaces of herbarium specimens included in the study.

\section{Materials and Methods}

\section{Plant Material}

The material included in the study was collected by the authors during field trips carried out between 2014 and 2017 in different parts of Turkey. Herbarium specimens are deposited in the Herbarium of the Faculty of Pharmacy of İstanbul University (ISTE). A list of the taxa included in the study was given in Table 1.

Table 1. List of voucher specimens of Euphorbia sect. Pithyusa studied in the study (* Endemic).

\begin{tabular}{|c|c|}
\hline Species & Voucher specimens (ISTE) \\
\hline E. cheiradenia Boiss. \& Hohen. & Şanlıurfa, Tektek Mountain National Park, 460m, 18.vi.2015, İ.Genç 2398, Ş.Kültür. \\
\hline E. erythrodon Boiss. \& Heldr. & $\begin{array}{l}\text { Erzincan, Sipikor mountain pass, 1400m, 25.vii.2015, İ.Genç 2463, A. Kandemir. Antalya, } \\
\text { Bozburun mountain, } 1600 \mathrm{~m}, 27 . v i i .2017, \text { I. Genç 2564, I.G. Deniz, G. Ecevit Genç. }\end{array}$ \\
\hline
\end{tabular}

E. macroclada Boiss.

E. niciciana Borbás ex Novák

E. pannonica Host

*E. pestalozzae Boiss.

E. petrophila C.A.Meyer

*E. pisidica Hub.-Mor.\&M.S.Khan

E. seguieriana Necker

E. smirnovii Geltman

E. thessala (Form.) Degen \& Dörf.

*E. yildirimlii Dinç
Isparta, Isparta-Eğirdir, roadside, 990m, 9.vii.2014, İ.Genç 2210, S. Yüzbaşıŏlu. Sivas, Tokat-Sivas road, near Kızıliniş, roadsides, 700m, 22.vii.2015, I. Genç 2445. Erzincan-Erzurum road, roadsides, 1510m, 23.vii.2015, İ.Genç 2448. Şanlıurfa, Tektek Mountain National Park, 410m, 18.vi.2015, I.Genç 2392, Ş.Kültürr. Van-Erciş road, near Van Lake, 1750m, 24.vii.2015, I. Genç 2454.

Edirne, Edirne-Uzunköprü, roadside, 70m, 6.vi.2015, I. Genç 2310, G. Ecevit Genç. Kırklareli, Mahya Mountain, 720m, 17.viii.2014, İ.Genç 2251, G. Ecevit Genç. Adapazarı, Serindere valley, 760m, 11.vii.2014, I.Genç 2235, S. Yüzbaşıŏlu.

Kırklareli, Kırklareli-Edirne, roadside, 280m, 5.vi.2015, I.Genç 2306, G. Ecevit Genç. İstanbul, Dağyenice-Kalfaköy, roadsides, 110m, 18.vii.2016, I.Genç 2477, G. Ecevit Genç.

Antalya, Kuhu mountain, Çığlıkara, 1650m, 27.vi.2014, İ.Genç 2168, İ.G.Deniz. Kızlarsivrisi, 1650m, 26.vi.2014, I. Genç 2161, I. G.Deniz. Saklıkent, 1780m, 30.vii.2016, I.Genç 2499.

Kastamonu, Kastamonu-Sinop, roadsides, 720m, 14.vii.2015, I.Genç 2419, G. Ecevit Genç. Çankırı, Ilgaz Mountain National Park, 1900m, 14.vii.2015, İ.Genç 2435, G. Ecevit Genç.

Burdur, Altınyayla-Gölhisar road, Dirmil pass, 1585m, 23.vi.2014, İ.Genç 2114, G. Ecevit Genç.

Ĭğdır-Doğubeyazıt, roadsides, 1500m, 23.vii.2015, İ.Genç 2451. Ăgrı, between DoğubeyazıtÇaldıran, roadsides, 2600m, 24.vii.2015, İ.Genç 2453. Van, Erciş-Van roadsides, 1650m, 24.vii.2015, İ.Genç 2456.

Erzincan, Ergan mountain, 1510m, 25.vii.2015, İ.Genç 2468, A. Kandemir.

Kırklareli, Kırklareli-Pınarhisar, roadside, 190m, 5.vi.2015, I.Genç 2304, G. Ecevit Genç.

Eskişehir, Sivrihisar, Aşağıkepen village, gypsum slopes, 900m, 26.viii.2014, İ.Genç 2267, G. Ecevit Genç. 
The classification based on the recent molecular phylogenetic study was used (Riina et al. 2013).

\section{Morphological Investigations}

Capsule, cauline leaf and cyathial gland morphologies were investigated as described below. The structures of the cyathial glands were examined using their photographs taken in the natural habitats of the plants or from herbarium materials when needed. Cyathial gland shapes and cyathial gland appendages were regarded as diagnostic characters for each taxon. To ensure stability and limit the range of variation in cyathial gland characters within taxa, several samples were investigated and photographed for each taxa (if available, because some of the studied samples were low in number).

The quantitative capsule characters were measured using different numbers of capsules depending on the material used. The number of capsules ranged from three in one population to a maximum of 24 in four populations because of the limited distribution of some taxa $(E$. pisidica, E. smirnovii, E. thessala and E. yildirimlii). For species with wider distributional ranges (e.g. $E$. macroclada and E. niciciana), populations from different parts of Turkey were selected. Only mature capsules were used for measurement. The capsules were examined in terms of size (length $\times$ width), shape, color and surface structures. Widths of the capsules were measured from the widest point. All measurement data of capsules were obtained under a stereomicroscope (Leica S8APO) with a camera attachment (Leica DFC295).

Sculpturing characteristics of capsule and cauline leaf surfaces were based on investigations of capsules and leaves mounted directly on stubs, attached with double adhesive tape and coated with a gold layer. Morphological observations concerning sculpturing were carried out with a FEI Quanta 450 FEG-EDS scanning electron microscope (SEM). All leaves were scanned from both surfaces. The terminology of macro- and micromorphology were based on Harris \& Harris (1994) and Stearn (2004).

\section{Results}

The investigations of cyathial glands showed that they vary in shape and colour (see Fig. 1 for all cyathial gland visuals and Table 2 for cyathial gland shapes and the appendages). The majority of the cyathial glands are yellow to yellowish-green in colour while cyathial glands of E. erythrodon, E. petrophila and E. smirnovii are red to purplish (Figs. 1b, i, 1). Reddish cyathial glands were also seen in E. cheiradenia which have normally yellowish cyathial glands (Fig. 1a).

There was no significant difference in cyathial gland size between the taxa. The cyathial gland number of all investigated species except E. pestalozzae was found to be four but some E. pestalozzae specimens with five cyathial glands were also determined (Fig. 1h). Cyathial gland shapes are elliptic, trapezoid-elliptic or reniform. Some species are hornless but truncate (E. glareosa, E. niciciana, E. pannonica and E. seguieriana) (Figs, 1c, f, $\mathrm{g}, \mathrm{k})$. Most species are characterized by their horned appendages. The horns are either short, as in $E$. erythrodon, E. petrophila and E. smirnovii (Figs. 1b, i, 1), long as in E. pisidica (Fig. 1j) or lobate and denticulate as in E. cheiradenia, E. macroclada and E. thessala (Figs. 1a, d, m). E. thessala (Fig. 1m) has the longest horns among the studied species. Although it varied for some species, the number of cyathial gland horns is often two. Polymorphism has also been observed in some species, i.e. E. cheiradenia (Fig. 1a) and E. thessala (Fig. 1m) with two horns or denticulate ones.

The morphological characters related with capsules and cauline leaf surfaces of the studies species are presented in Table 2. Stereomicroscope images of the capsules are given in Fig. 2 and SEM micrographs of the studied species are provided in Figs. 3-4.

According to the morphometric measurements, the longest capsule (c. $6.7 \mathrm{~mm}$ long) occurred in $E$. macroclada (Fig. 2d) followed by E. cheiradenia (Fig. 2a) and E. pisidica (Fig. 2i) with c. 5 and $4.75 \mathrm{~mm}$, respectively). The shortest capsule (c. $1.9 \mathrm{~mm}$ long) was determined to be in E. niciciana (Fig. 2e). The widest capsule (c. $4.45-5.5 \mathrm{~mm}$ wide) was seen in E. macroclada (Fig. 2d). The narrowest capsule (c. $2.25 \mathrm{~mm}$ wide) was in E. petrophila (Fig. 2h), followed by E. niciciana and $E$. seguieriana with capsules about $2.4 \mathrm{~mm}$ width (Figs. $2 \mathrm{e}$, $2 \mathrm{j})$.

The capsule shapes of the studied species vary from subglobose (E. glareosa and E. niciciana) to conical (Figs. 1, 2). Capsules of all taxa are trilobate, but the significance of the lobes varies from shallow to deep (Fig. $1,2)$.

The micromorphological features of capsule surfaces are summarized in Table 2 . The capsule surface is mostly covered with nipple-like projections (papillatemammillate) (7 taxa) and others are covered with little rounded or hillock-like elevations (colliculate). The capsules of E. erythrodon (Fig. 3b), E. glareosa (Fig. 3c) and E. macroclada (Fig. 3d) are covered with long and nearly acute projections (papillate), while both projection types were observed in E. pannonica, E. petrophila, E. smirnovii and E. yildirimlii. The type of capsule indumentum varied from glabrous to villous (Fig. 1, 2).

The investigation of leaves showed that dorsal and ventral cauline leaf surface sculptures are correspondent, so only dorsal cauline leaf surface is discussed. Cauline leaf dorsal surface properties are summarized in Table 2. The cauline leaf surfaces are papillate-mammillate in most of the studied species. The colliculate surfaces are also observed in two species, E. seguieriana (Fig. 4j) and E. thessala (Fig. 41). 
Table 2. The morphological features of capsules, cauline leaf surfaces and cyathial glands of the examined Euphorbia species (w: width; l: length).

\begin{tabular}{|c|c|c|c|c|c|}
\hline Taxa & $\begin{array}{l}\text { Capsule size } \\
\qquad(w \times l)\end{array}$ & $\begin{array}{c}\text { Capsule } \\
\text { shape }\end{array}$ & Capsule surface & $\begin{array}{l}\text { Cauline Leaf } \\
\text { dorsal surface }\end{array}$ & $\begin{array}{l}\text { Cyathial gland } \\
\text { shape }\end{array}$ \\
\hline E. cheiradenia & $3-3.6 \times 4.8-5$ & $\begin{array}{c}\text { Conical, shallowly } \\
\text { trilobate }\end{array}$ & Colliculate, glabrous & $\begin{array}{l}\text { Colliculate- } \\
\text { mammillate }\end{array}$ & $\begin{array}{l}\text { Elliptic, two- or } \\
\text { multi-horned }\end{array}$ \\
\hline E. erythrodon & $2.7-3.05 \times 3.25-3.75$ & $\begin{array}{l}\text { Ovoid-conical, } \\
\text { trilobate }\end{array}$ & $\begin{array}{l}\text { Papillate, glabrous to } \\
\text { sparingly villose }\end{array}$ & Papillate & $\begin{array}{c}\text { Trapezoid-elliptic, } \\
\text { hornless or two } \\
\text { short horned }\end{array}$ \\
\hline E. glareosa & $2.5-3.3 \times 2.4-3.2$ & $\begin{array}{l}\text { Subglobose-ovoid, } \\
\text { shallowly trilobate }\end{array}$ & $\begin{array}{l}\text { Papillate, glabrous to } \\
\text { sparingly villose }\end{array}$ & Mammillate & $\begin{array}{c}\text { Trapezoid-elliptic, } \\
\text { hornless }\end{array}$ \\
\hline E. macroclada & $4.45-5.5 \times 4.2-6.7$ & $\begin{array}{l}\text { Subglobose-ovoid, } \\
\text { shallowly trilobate }\end{array}$ & $\begin{array}{c}\text { Papillate, glabrous to } \\
\text { villose }\end{array}$ & Papillate & $\begin{array}{c}\text { Elliptic, two lobate } \\
\text { or simple horned to } \\
\text { denticulate }\end{array}$ \\
\hline E. niciciana & $2.4-3 \times 1.95-2.5$ & $\begin{array}{l}\text { Subglobose-ovoid, } \\
\text { deeply trilobate }\end{array}$ & Colliculate, glabrous & Mammillate & $\begin{array}{c}\text { Trapezoid-elliptic, } \\
\text { hornless }\end{array}$ \\
\hline E. pannonica & $2.6-3.35 \times 2.95-3.75$ & $\begin{array}{l}\text { Ovoid-conical, } \\
\text { trilobate }\end{array}$ & $\begin{array}{c}\text { Papillate- } \\
\text { mammillate, } \\
\text { glabrous to villose }\end{array}$ & Mammillate & Trapezoid, hornless \\
\hline E. pestalozzae & $3.55-3.65 \times 4.25-4.4$ & $\begin{array}{l}\text { Conical, shallowly } \\
\text { trilobate }\end{array}$ & Colliculate, glabrous & Mammillate & $\begin{array}{l}\text { Elliptic-truncate, } \\
\text { two horned }\end{array}$ \\
\hline E. petrophila & $2.25-2.6 \times 2.5-3$ & $\begin{array}{l}\text { Ovoid-conical, } \\
\text { shallowly trilobate }\end{array}$ & $\begin{array}{l}\text { Papillate- } \\
\text { mammillate, } \\
\text { glabrous }\end{array}$ & Papillate & $\begin{array}{c}\text { Truncate-reniform, } \\
\text { two horned }\end{array}$ \\
\hline E. pisidica & $2.5-3.3 \times 3.3-4.75$ & $\begin{array}{c}\text { Conical, shallowly } \\
\text { trilobate }\end{array}$ & Colliculate, glabrous & Mammillate & $\begin{array}{l}\text { Elliptic, two- or } \\
\text { multi- long horned }\end{array}$ \\
\hline E. seguierana & $2.4-3.2 \times 2.6-3.2$ & $\begin{array}{l}\text { Subglobose-ovoid, } \\
\text { deeply trilobate }\end{array}$ & Colliculate, glabrous & Colliculate & $\begin{array}{l}\text { Trapezoid-elliptic, } \\
\text { hornless }\end{array}$ \\
\hline E. smirnovii & $2.6-3.7 \times 3.6-3.75$ & $\begin{array}{l}\text { Ovoid-conical, } \\
\text { shallowly trilobate }\end{array}$ & $\begin{array}{l}\text { Papillate- } \\
\text { mammillate, } \\
\text { glabrous }\end{array}$ & $\begin{array}{l}\text { Papillate- } \\
\text { mammillate }\end{array}$ & $\begin{array}{l}\text { Trapezoid, two } \\
\text { short horned }\end{array}$ \\
\hline E. thessala & $2.95-3.5 \times 3.75-4.1$ & $\begin{array}{l}\text { Conical, shallowly } \\
\text { trilobate }\end{array}$ & Colliculate, glabrous & Colliculate & $\begin{array}{l}\text { Trapezoid-elliptic, } \\
\text { two horned }\end{array}$ \\
\hline E. yildirimlii & $3.05-4.1 \times 2.3-4.2$ & $\begin{array}{l}\text { Subglobose-ovoid, } \\
\text { shallowly trilobate }\end{array}$ & $\begin{array}{c}\text { Papillate- } \\
\text { mammillate, } \\
\text { glabrous to sparingly } \\
\text { villose }\end{array}$ & $\begin{array}{l}\text { Papillate- } \\
\text { mammillate }\end{array}$ & $\begin{array}{l}\text { Elliptic, two short } \\
\text { horned }\end{array}$ \\
\hline
\end{tabular}

The density of the projections of cauline leaf surfaces decreased by aging of the plants. For example, the immature individuals of E. cheiradenia are covered with dense mammillate projections, whereas the mature ones are covered with colliculate ornamentations. With the exception of E. pisidica with pubescent leaves, the remained taxa are glabrous (Fig. 4i). Capsule and cauline leaf surfaces of all investigated taxa are covered with epicuticular wax secretion forming fine platelets. As the plant matures, surface secretions may be eroded (Figs. 3n, 4n). 


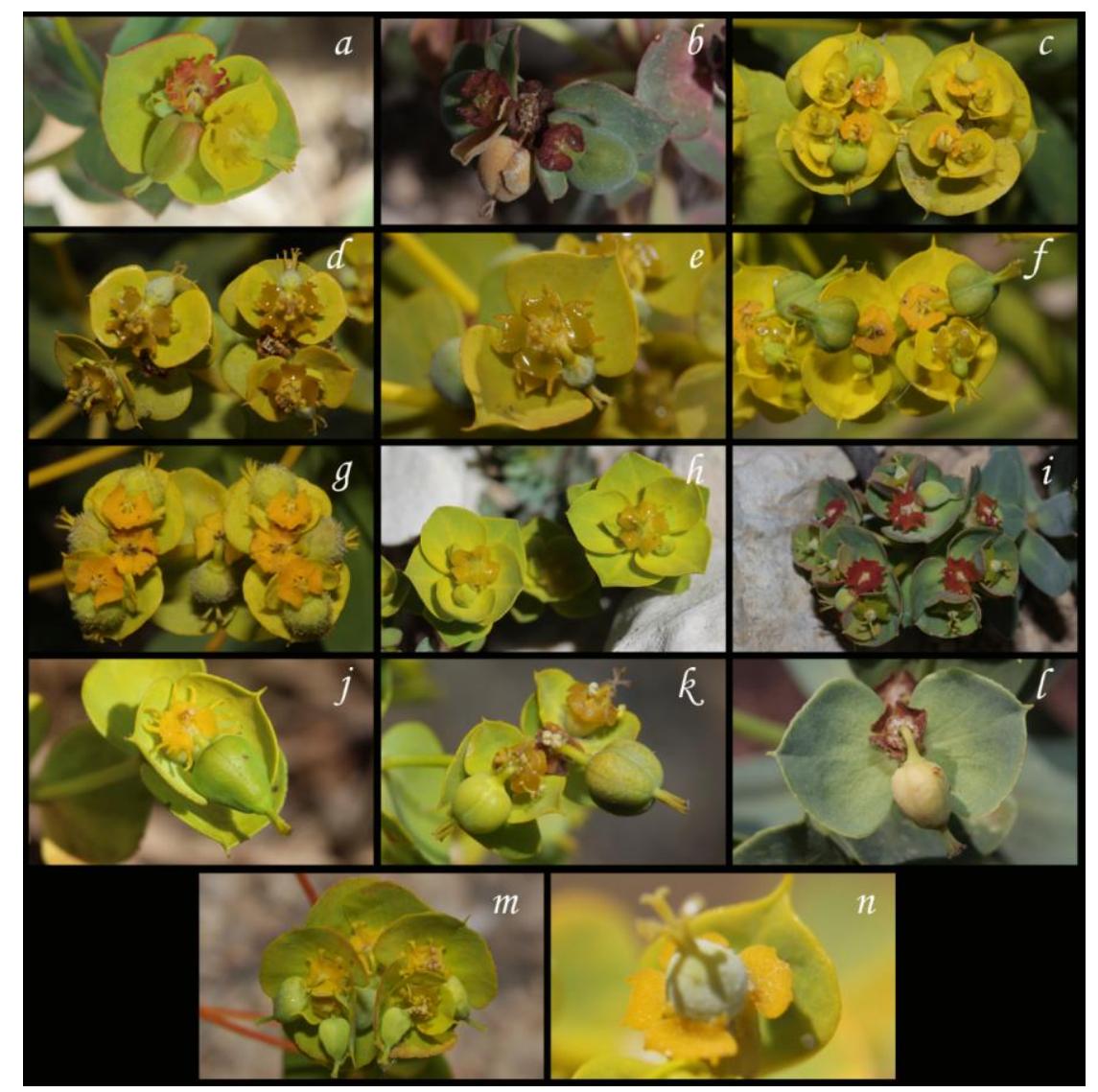

Fig. 1. Photographs of cyathial glands of studied taxa: a. E. cheiradenia, b. E. erythrodon, c. E. glareosa, d. \& e. E. macroclada, f. E. niciciana, g. E. pannonica, h. E. pestalozzae, i. E. petrophila, j. E. pisidica, k. E. seguierana, l. E. smirnovii, m. E. thessala, n. E. yildirimlii.

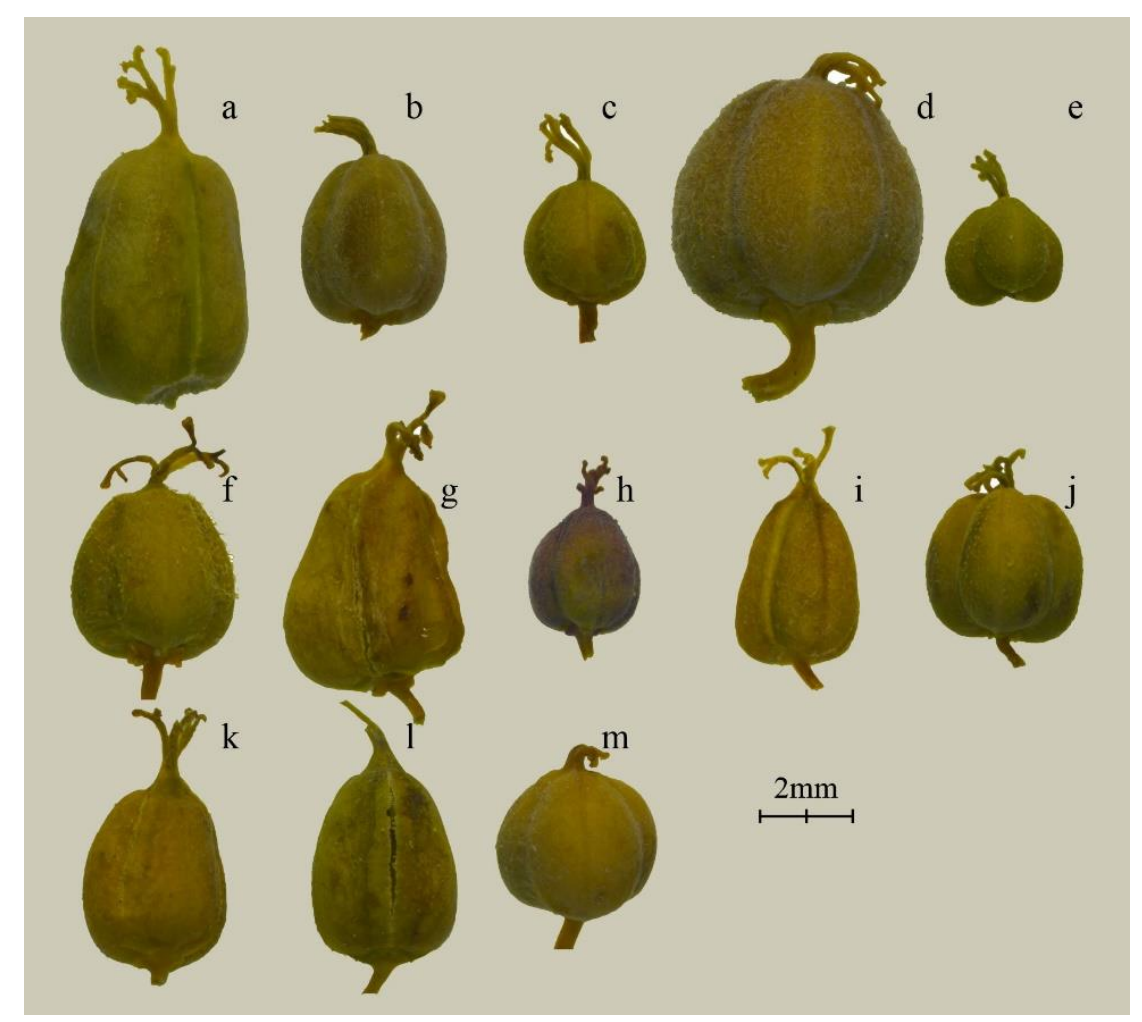

Fig. 2. Stereomicroscopic micrographs of capsules of studied taxa: a. E. cheiradenia, b. E. erythrodon, c. E. glareosa, d. E. macroclada, e. E. niciciana, f. E. pannonica, g. E. pestalozzae, h. E. petrophila, i. E. pisidica, j. E. seguierana, k. E. smirnovii, l. E. thessala, m. E. yildirimlii. 


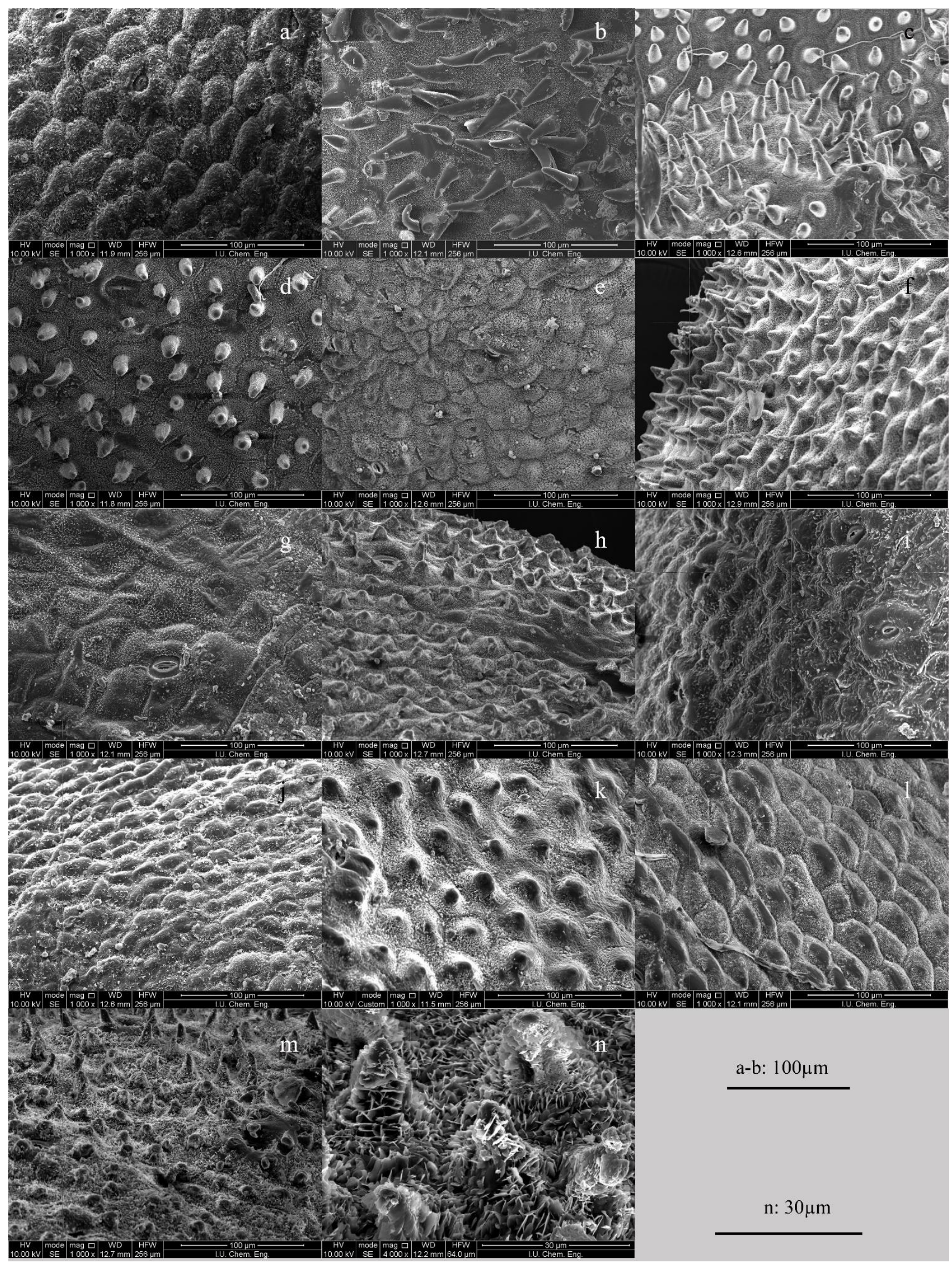

Fig. 3. Scanning electron micrographs of capsule surface of studied taxa: a. E. cheiradenia, b. E. erythrodon, c. E. glareosa, d. E. macroclada, e. E. niciciana, f. E. pannonica, g. E. pestalozzae, h. E. petrophila, i. E. pisidica, j. E. seguierana, k. E. smirnovii, l. E. thessala, m. E. yildirimlii, n. epicuticular wax. 


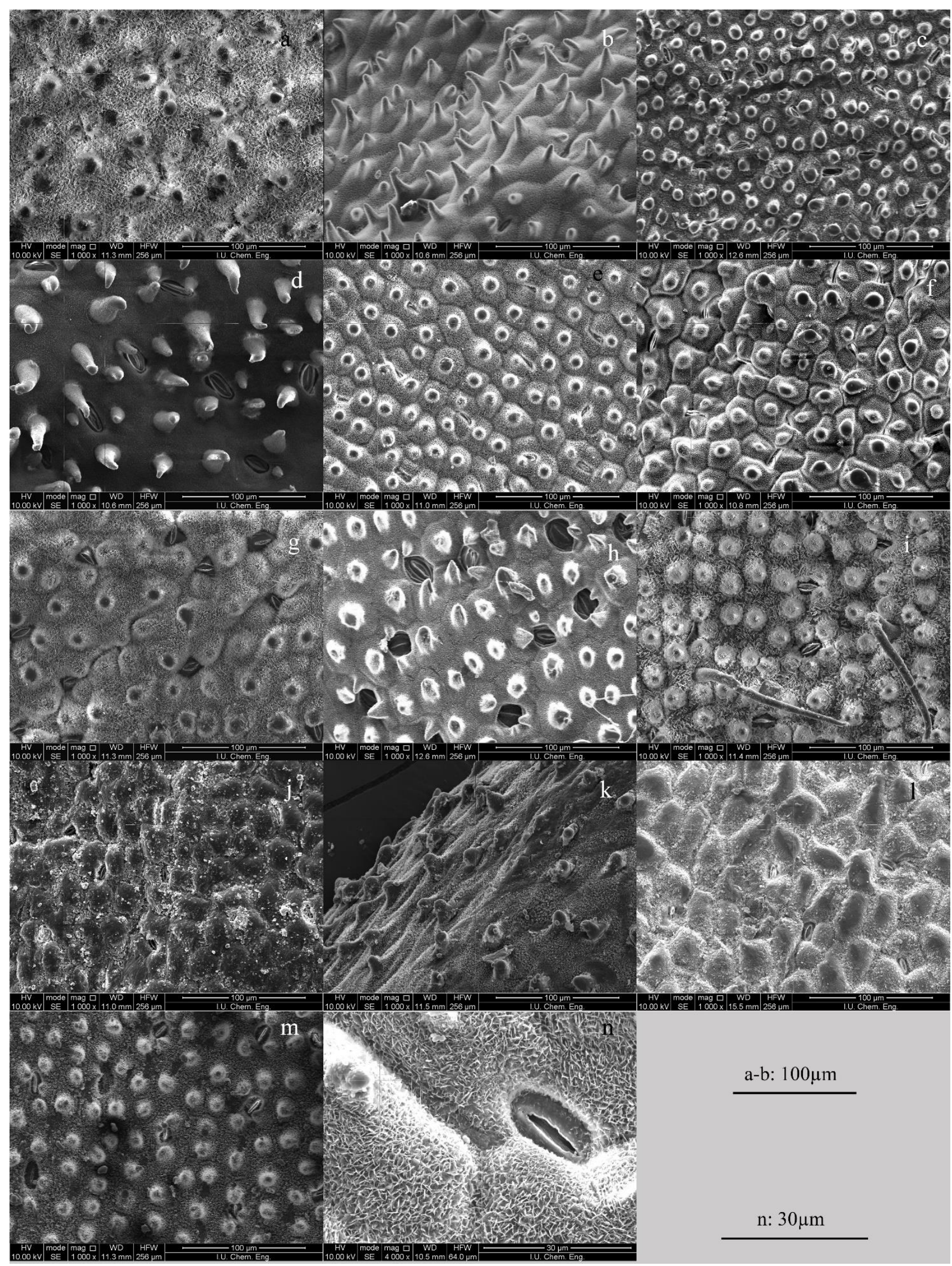

Fig. 4. Scanning electron micrographs of cauline leaf surface of studied taxa: a. E. cheiradenia, b. E. erythrodon, c. E. glareosa, d. E. macroclada, e. E. niciciana, f. E. pannonica, g. E. pestalozzae, h. E. petrophila, i. E. pisidica, j. E. seguierana, k. E. smirnovii, l. E. thessala, m. E. yildirimlii, n. epicuticular wax. 


\section{Discussion}

Based on capsule micromorphology, two groups are recognized, one including species with colliculate capsule surface (E. cheiradenia, E. niciciana, E. pestalozzae, E. pisidica, E. seguierana and E. thessala) and the other with species with papillate-mammillate capsule surface. According to the result of this study, micromorphology of capsule surfaces is more useful as an identification character compared to the cauline leaf surfaces because the cauline leaf surface properties vary as the plant matures.

Members of section Pithyusa in Iran are characterized by a conical capsule shape (Pahlevani et al. 2015), however subglobose and ovoid capsule shapes are recorded in our present study.

Our results related to capsule sizes correspond to the results of Pahlevani et al. (2015) about the species with wider distribution ranges which also occur in Iran $(E$. cheiradenia, E. glareosa, E. macroclada and $E$. seguieriana). However, the capsule shape of E. glareosa and E. seguieriana differs from Iranian members. According to Pahlevani et al. (2015) these two species have conical shallowly trilobate capsules but the specimens in Turkey have subglobose clearly trilobate capsules.

The results show that capsule size may be used to determine some species morphologically close to each other. For example, E. smirnovii can be distinguished from $E$. petrophila with larger capsules as in the case of E. macroclada and E. glareosa. Morphology of cyathial glands shapes, their colour and appendages have been

\section{References}

1. Bruyns, P.V., Mapaya, R.J. \& Hedderson, T. 2006. A new subgeneric classification for Euphorbia (Euphorbiaceae) in southern Africa based on ITS and psbA-trnH sequence data. Taxon, 55: 397-420.

2. Can, L. \& Küçüker, O. 2015. Seed morphology and surface microstructure of some Euphorbia (Euphorbiaceae) taxa distributed in Turkey-in-Europe. Turkish Journal of Botany, 39(3): 449-457.

3. Dorsey, B.L., Heavermans, T., Aubriot, X., Morawetz, J.J., Riina, R., Steinmann V.W. \& Berry, P.E. 2013. Phylogenetics, morphological evolution, and classification of Euphorbia subgenus Euphorbia. Taxon, 62: 291-315.

4. Geltman, D.V. (2015). Phytogeographical analysis of Euphorbia subgenus Esula (Euphorbiaceae). Polish Botanical Journal, 60(2): 147-161.

5. Genç, İ. \& Kültür, Ş. 2016. Euphorbia akmanii (Euphorbiaceae), a new species from Turkey. Phytotaxa, 265: 112-120.

6. Harris, J.G. \& Harris, M.W. 1994. Plant identification terminology: an illustrated glossary. Spring Lake Publishing, Utah, 206 pp.

7. Horn, J.W., van Ee, B.W., Morawetz, J.J., Riina, R., Steinmann, V.W., Berry, P.E. \& Wurdack, K.J. 2012. Phylogenetics and the evolution of major structural useful tools for identifications of some species. The cyathial gland shapes are elliptic or trapezoid-elliptic for all investigated taxa, except E. petrophila. The gland shape is truncate-reniform of this species (Fig. 1i).

In terms of cyathial gland appendage characteristics, intraspecific variation was most commonly seen in $E$. macroclada. The appendages of this species vary from not very distinct horns to lobate-multifid horns. No similar variation is observed in other species.

The number of cyathial glands of sect. Pithyusa is reported as four by Riina et al. (2013). On the other hand, it has been determined that some specimens of $E$. pestalozzae have five cyathial glands in this study.

The variation in the number of horns of E. cheiradenia cyathial glands has been previously reported by Salmaki et al. (2011). But no colour variation was reported. Reddish cyathial glands, in addition to yellow cyathial glands were also observed in some specimens of $E$. cheiradenia included in our present study.

The observed morphological characters of capsule and cyathial glands can be used as effective diagnostic characters to separate some close species (eg. $E$. macroclada-E. yildirimlii; E. petrophila-E. smirnovii; E. pannonica-E. glareosa) in the sect. Pithyusa of the genus Euphorbia.

\section{Acknowledgement}

This study was financially supported by the Scientific and Technological Research Council of Turkey (TUBITAK) with the Project no. 114Z121.

characters in the giant genus Euphorbia L. (Euphorbiaceae). Molecular Phylogenetics and Evolution, 63(2): 305-326

8. Öztekin, M. 2012. Euphorbia L. pp. 414-424. In: Güner, A., Aslan, S., Ekim, T., Vural, M. \& Babaç, M.T. (Eds.) Türkiye Bitkileri Listesi (Damarl Bitkiler). Nezahat Gökyiğit Botanik Bahçesi ve Flora Araştırmaları Derneği Yayını, İstanbul, $1290 \mathrm{pp}$.

9. Pahlevani, A.H. \& Akhani, H. 2011. Seed morphology of Iranian annual species of Euphorbia (Euphorbiaceae). Botanical journal of the Linnean Society, 167: 212-234.

10. Pahlevani, A.H., Liede-Schumann, S. \& Akhani, H. 2015. Seed and capsule morphology of Iranian perennial species of Euphorbia (Euphorbiaceae) and its phylogenetic application. Botanical journal of the Linnean Society, 177: 335-377.

11. Pahlevani, A.H. 2017. Four new species of Euphorbia sect. Pithyusa (subg. Esula, Euphorbiaceae) from SW Asia. Phytotaxa, 312: 83-93.

12. Pahlevani, A.H., Feulner, M., Weig, A. \& LiedeSchumann, S. 2017. Molecular and morphological studies disentangle species complex in Euphorbia sect. Esula (Euphorbiaceae) from Iran, including two new species. Plant Systematics and Evolution, 303: 139-164. 
13. Peirson, J.A., Bruyns, P.V., Riina, R., Morawetz, J.J. \& Berry, P.E. 2013. A molecular phylogeny and classification of the largely succulent and mainly African Euphorbia subg. Athymalus (Euphorbiaceae). Taxon, 62: 1178-1199.

14. Radcliffe-Smith, A. 1982. Euphorbia L. Pp. 571-630. In: Davis, P.H., Edmondson, J.R., Mill, R.R. \& Kit Tan (Eds.) Flora of Turkey and the East Aegean Islands, vol. 7. Edinburgh University Press, Edinburgh, 947 pp.

15. Riina, R., Peirson, J.A., Geltman, D.V., Molero, J., Frajman, B., Pahlevani, A., Barres, L., Morawetz, J.J., Salmaki, Y., Zarre, S., Kryukov, A., Bruyns, P.V. \& Berry, P.E. 2013. A worldwide molecular phylogeny and classification of the leafy spurges, Euphorbia subgenus Esula (Euphorbiaceae). Taxon, 62(2): 316-342.

16. Salmaki, Y., Zarre, S., Esser, H.-J. \& Heubl, G. 2011. Seed and gland morphology in Euphorbia (Euphorbiaceae) with focus on their systematic and phylogenetic importance, a case study in Iranian highlands. Flora, 206(11): 957-973.
17. Steinmann, V.W. \& Porter, J.M. 2002. Phylogenetic relationships in Euphorbieae (Euphorbiaceae) based on ITS and ndhF sequence data. Annals of the Missouri Botanical Garden, 89: 453-490.

18. Stearn, W.T. 2004. Botanical Latin. $1^{\text {st }}$ paperback ed. Timber Press, Portland, 546 pp.

19. Yang, Y., Riina, R., Morawetz, J.J., Heavermans, T., Aubriot, X. \& Berry, P.E. 2012. Molecular phylogenetics and classification of Euphorbia subgenus Chamaesyce (Euphorbiaceae). Taxon, 61: 764-789.

20. Zimmermann, N.F.A., Ritz, C.M. \& Hellwig, F.H. 2010. Further support for the phylogenetic relationships within Euphorbia L. (Euphorbiaceae) from nrITS and trnL-trnF IGS sequence data. Plant Systematics and Evolution, 286: 39-58. 
